\title{
ASPEKTI KVALITETE ŽIVOTA ŽENA OBOLJELIH OD RAKA DOJKE U KREIRANJU REHABILITACIJSKOG PROCESA
}

\author{
${ }^{1}$ Karlo Ostrogonac, ${ }^{2}$ Melita Rukavina, ${ }^{2}$ Ivana Crnković \\ ${ }^{1}$ Klinički bolnički centar Sestre Milosrdnice, \\ ${ }^{2}$ Zdravstveno veleučilište Zagreb, Hrvatska \\ Rad je primljen 13.06. 2016. Rad je recenziran 01.09.2016. Rad je prihvaćen 07.10.2016
}

\section{SAŽETAK}

UVOD: Pojam kvalitete života zbog svoje multidimenzionalnosti neizostavna je smjernica i evaluacijski instrument $\mathrm{u}$ rehabilitacijskom procesu onkoloških pacijenata. Kreiranje smjernica temeljenih na faktorima koji narušavaju kvalitetu života, neophodno je za određivanje ishoda liječenja onkoloških pacijenata.

CILJ: Cilj ovoga rada bio je utvrditi stupanj kvalitete života kod onkoloških bolesnica nakon liječenja raka dojke, te odrediti faktore koji utječu na samoprocjenu kvalitete života unutar te populacije na temelju kojih je moguće odrediti smjernice u rehabilitacijskom procesu.

ISPITANICI I METODE: U istraživanju je sudjelovalo 39 ispitanica. Korišten je uzorak ispitanica iz različitih dijelova Republike Hrvatske. U svrhu ovog istraživanja korišten je Indeks osobne dobrobiti (PWI) za procjenu kvalitete života osoba i dobrobiti poslije provedenog onkološkog liječenja te upitnik za samoprocjenu kvalitete života EORTC QLQ-C30 verzija 3.0.

REZULTATI: Rezultati ovog istraživanja pokazali su da ukupna kvaliteta života žena oboljelih od raka dojke ne odstupa značajno od rezultata koji su zabilježeni u zdravoj populaciji. Međutim, postoje domene u kojima su prisutne lošije procjene koje na direktan način utječu na procjenu ostalih ispitanih područja povezanih s kvalitetom života. Prema samoprocjeni ispitanica ukupna kvaliteta života najviše je povezana s poteškoćama sa spavanjem, novčanim neprilikama te probavnim smetnjama.

ZAKLJUČAK: Objektivizacija navedenih faktora koji narušavaju kvalitetu života žena oboljelih od raka dojke polazna je odrednica u izradi smjernica u rehabilitacijskom procesu u cilju unapređenja intervencijskih postupaka u procesu liječenja.

Ključne riječi: kvaliteta života, rak dojke, smjernice u kreiranju rehabilitacijskog procesa

Kontakt: Karlo Ostrogonac

e-mail: ostrogonac.karlo@gmail.com 


\section{UVOD}

Tumori su danas sve učestalija dijagnoza, a po smrtnosti među vodećim bolestima suvremenog svijeta (1). Rak dojke je ozbiljan javnozdravstveni problem i najčešća je suvremena maligna bolest ženske populacije (2). Statistički podaci govore kako rak dojke čini oko $25 \%$ svih malignoma kod žena, što je gotovo dvostruko više nego svi ginekološki karcinomi zajedno. Vrh incidencije raka dojke s obzirom na dob bolesnica je oko 60. godine života, iako najnovija epidemiološka istraživanja jasno pokazuju kako se vrh krivulje incidencije raka dojke postupno pomiče prema mlađoj životnoj dobi, s osobitim porastom incidencije bolesti u populaciji od 30. do 40 . godine života (3). Jedan od glavnih problema u liječenju raka dojke je raznoliko biološko ponašanje tumora dojke. Unatoč prepoznavanju bolesnica $s$ nepovoljnim tradicionalnim prognostičkim čimbenicima, u kliničkom praćenju izdvajaju se dvije skupine bolesnica: one koje će biti izliječene ili će ući u razdoblje dugotrajne remisije bolesti, te one kod kojih će razmjerno brzo doći do ponovnog pojavljivanja bolesti. Prepoznavanje ove druge skupine bolesnica, koje treba liječiti agresivnijom kemoterapijskom shemom, od velikog je značenja za uspješno liječenje bolesnica s rakom dojke. Stoga su danas brojna istraživanja usmjerena na prepoznavanje novih pokazatelja koji mogu predvidjeti biološko ponašanje tumora, odnosno tijek bolesti (4).

Srž pojma kvaliteta života kod svakog pojedinca je njegov doživljaj zadovoljstva načinom života i njegovim tokom i uvjetima, perspektivom, mogućnostima i ograničenjima koje ima svaki pojedinac u svom životu (5). Ta procjena, osnovana kako na individualnom iskustvu tako i na aspiracijama, željama i vrijednostima pojedinca, određena je psihofiziološkim sklopom karakteristika pojedinca i objektivnim uvjetima u kojima živi. Kognitivne i konativne osobine svakog pojedinca određuju raspon i kvalitetu interakcija s okolinom, njegovu prilagodljivost promjenama u fizičkoj i socijalnoj okolini, kao i promjenama koje se zbivaju unutar organizma (6). Fossa i sur. su u istraživanju o stabilnosti kvalitete života kod opće populacije i oboljelih od malignih bolesti, dobili podatak da oboljeli imaju lošije tjelesno i poslovno funkcioniranje, a kvaliteta života oboljelih značajno se pogoršava ukoliko boluju od još neke kronične bolesti (povišeni krvni tlak, dijabetes, psihološki distres). Mnoga istraživanja su pokazala da se psihička stanja, posebice anksioznost i depresivnost, javljaju kao medijatori zdravstvenog ishoda i subjektivne kvalitete života u situacijama bolesti (7).

Tri su studije proučile utjecaj rehabilitacije i fizioterapije na pacijente oboljele od raka koji pate od simptoma umora. Scialla i sur. proučavali su retrospektivno, na uzorku od 110 pacijenata koji su primali multidisciplinarnu rehabilitaciju na bolničkoj njezi, dok su Schwartz te Porock i sur. proučavali pacijente koji su radili po programima vježbi zasnovanima na kućnoj palijativnoj skrbi (8-10). U sva tri su slučaja rezultati ukazali na to da su pacijenti imali koristi od postupka, ali uslijed nedostatka randomiziranih istraživanja i relativno malih uzoraka, nemoguće je bilo izvući čvršće zaključke. Nije provedeno mnogo istraživanja na temu veza između subjektivnih primjedbi o slabosti i umoru i objektivnih mjerenja snage i funkcionalnosti te je na tom području potreban daljnji rad.

Ciljevi ovog rada bili su utvrditi stupanj kvalitete života kod žena oboljelih od raka dojke u cjelini i po domenama te ispitati povezanost različitih sociodemografskih obilježja ispitanica s njihovom kvalitetom života u svrhu izrade smjernica u rehabilitaciji žena oboljelih od raka dojke.

\section{METODE}

\section{Uzorak}

U istraživanju je sudjelovalo 39 ispitanica kojima je dijagnosticiran rak dojke. Populacija, iz koje je definiran prigodni uzorak, obuhvatla je žene koju su za vrijeme istraživanja bile članice udruga žena oboljelih od raka dojke s različitih područja Republike Hrvatske.

Prosječna dob ispitanica iznosila je 47,77 godina $(\mathrm{SD}=10,629)$, pri čemu je najmlađa ispitanica imala 22 godine, a najstarija 76 godina. Većina ispitanica imala je srednju stručnu spremu (njih 56,4 \%), a $61,5 \%$ ispitanica bilo je u braku. Prosjek vremena proteklog od postavljanja dijagnoze iznosio je 
3,3 godine $(\mathrm{SD}=3,04)$, s tim da je najkraće vrijeme od postavljanja dijagnoze do ispunjavanja upitnika iznosilo 11 mjeseci, a najduže 14 godina. Vrijeme proteklo od samog liječenja pa do ispunjavanja upitnika u prosjeku je iznosilo 2,8 godine $(S D=2,5), s$ rasponom od 11 mjeseci do 14 godina. Većina ispitanica nije bila uključena $\mathrm{u}$ rehabilitacijski proces nakon zahvata, dok ih je 10 ili 25,6 \% bilo u procesu rehabilitacije. Od svih ispitanica koje su bile uključene u neki oblik sportske aktivnosti sve su se tim sportom bavile isključivo rekreativno (tablica 1).

Tablica 1. Sociodemografske karakteristike ispitanika

\begin{tabular}{lcc}
\hline Varijable & N & $\%$ \\
\hline Stupanj obrazovanja & & \\
\hline Bez obrazovanja & 1 & 2,6 \\
\hline Osnovna škola & 3 & 7,7 \\
\hline Srednja škola & 22 & 56,4 \\
\hline Viša stručna sprema & 3 & 7,7 \\
\hline Visoka stručna sprema & 10 & 25,6 \\
\hline Bračni status & & \\
\hline Sama & 4 & 10,3 \\
\hline U braku & 24 & 61,5 \\
\hline Živi s partnerom & 5 & 12,8 \\
\hline U vezi & 5 & 12,8 \\
\hline Rastavljena & 1 & 2,6 \\
\hline Udovica & 0 & 0 \\
\hline Uključenost u rehabilitacijski proces & & \\
\hline Uključena & 10 & 25,6 \\
\hline Nije uključena & 29 & 74,4 \\
\hline Trenutačna uključenost u rehabilitacijski proces & & \\
\hline Uključena & 2 & 5,1 \\
\hline Nije uključena & 37 & 94,9 \\
\hline Uključenost u sportsku aktivnost & 5 & \\
\hline Uključena & 34 & 87,2 \\
\hline Nije uključena & & \\
\hline
\end{tabular}

\section{Mjerni instrumenti}

Za procjenu kvalitete života osoba poslije provedenog liječenja korišten je Indeks osobne dobrobiti (PWI, engl. Personal Wellbeing Index) (11). PWI je sastavni dio Međunarodnog Indeksa dobrobiti (IWI, engl. International Well Being Index) koji obuhvaća Indeks osobne dobrobiti i Indeks nacionalne dobrobiti (NWI, engl. National Wellbeing Index). U ovom istraživanju korišten je Indeks osobne dobrobiti koji se sastoji od sedam čestica koje se procjenjuju na skali od 0 do 10 (0 - nimalo nisam zadovoljan, 5 - i zadovoljan ni nezadovoljan, 10 - u potpunosti sam zadovoljan). Dobiveni rezultat se množi s 10 te se tako dobiva ukupni rezultat s rasponom od 0 do 100 pri čemu veći rezultat ukazuje na veći stupanj zadovoljstva životom (12). U prethodnim istraživanjima utvrđene su dobre metrijske karakteristike ovog indeksa na hrvatskoj populaciji (13).

Za samoprocjenu kvalitete života korišten je upitnik EORTC QLQ-C30 verzija 3.0. (engl. European Organization for Research and Treatment of Cancer's Quality of Life Questionnaire) (14). Upitnik se sastoji od pet funkcionalnih skala: tjelesno funkcioniranje, poslovno funkcioniranje, kognitivno funkcioniranje, emocionalno funkcioniranje i socijalno funkcioniranje; te tri skale simptoma: umor, bol, mučnina, povraćanje; skale općeg zdravstvenog statusa/kvalitete života i šest individualnih čestica simptoma najčešće povezanih s malignim oboljenjem: teškoće disanja, gubitak apetita, poremećaji spavanja, konstipacija, diarea i financijske teškoće kao posljedica bolesti i tretmana. Ukupno se sastoji od 30 čestica. Sve čestice bodovane su na Likertovoj skali od 1 do 4 pri čemu 1 znači nimalo, a 4 izrazito. Izuzetak je skala općeg zdravlja/kvalitete života bodovana na 7-bodovnoj linearnoj analognoj skali. Procjena kvalitete života odnosi se na razdoblje od sedam dana koji su prethodili ispitivanju. Svi rezultati dobiveni na funkcionalnim skalama kao i pojedinim česticama su linearno transformirani i pretvoreni u skalu od 0 do 100 , pri čemu viši rezultat na funkcionalnim skalama označava bolje funkcioniranje, dok visok rezultat na skalama simptoma označava prisutnost većeg broja simptoma odnosno problema (15). Korišten je hrvatski prijevod upitnika koji je pokazao dobre metrijske karakteristike za uzorak ispitanika sa i bez malignog oboljenja (16).

\section{Postupak}

Istraživanje se provodilo od početka kolovoza 2015. do kraja rujna 2015. godine. Anketiranje sudionica provedeno je putem udruga žena oboljelih od raka dojke. Sve ispitanice informirane su u koju svrhu se istraživanje provodi te su dobrovoljno pristale sudjelovati u istraživanju. Vrijeme potrebno za 
ispunjavanje cjelokupnog upitnika kretalo se oko 20 minuta. Nacrt i postupak istraživanja osmišljen je i ostvaren u skladu s općim načelima provedbe istraživanja u kojima su sudionici ljudi.

Dobiveni podaci analizirani su pomoću statističkog paketa SPSS Statistics 17.0. Prikazana je osnovna deskriptivna statistika za pojedine varijable (aritmetička sredina, standardna devijacija te minimalne i maksimalne vrijednosti na pojedinim skalama) te povezanost među varijablama pomoću Pearsonovog koeficijenta korelacije.

\section{REZULTATI}

Kako bi utvrdili zadovoljstvo životom žena oboljelih od raka dojke izračunali smo prosječne vrijednosti za pojedine skale. Promatrajući zadovoljstvo životom po pojedinim domenama Indeksa osobne dobrobiti možemo vidjeti da su ispitanice najviše zadovoljne odnosima s bližnjima $(M=75,90)$, pripadnosti okolini $(M=68,46)$ i osjećajem sigurnosti $(M=66,41)$ (tablica 2). Dobivena ukupna prosječna vrijednost za cijelu skalu $(\mathrm{M}=64,39)$ ukazuju da ispitanice liječene od raka dojke po procjeni kvalitete života ne odstupaju od vrijednosti koje se mogu naći u zdravoj populaciji. Procjena osobne dobrobiti nakon liječenja, kreće se u okvirima od 60 do $80 \%$ skalarnog maksimuma što se prema homeostatskom modelu smatra rezultatom unutar prosjeka koji postižu zdrave osobe (17).

Tablica 2. Prosječne vrijednosti na Indeksu osobne dobrobiti (PWI)

\begin{tabular}{lccccc}
\hline Varijabla & $N$ & Minimum & Maksimum & $\bar{X}$ & SD \\
\hline PWI prosječne vrijednosti & 39 & 24,3 & 100,00 & 64,39 & 18,768 \\
\hline Zadovoljstvo životom u cijelosti & 39 & 30 & 100 & 68,72 & 23,190 \\
\hline Životni standard & 39 & 20 & 100 & 58,97 & 28,265 \\
\hline Zdravlje & 39 & 20 & 100 & 59,49 & 24,274 \\
\hline Postignuće & 39 & 20 & 100 & 62,56 & 23,700 \\
\hline Odnosi s bližnjima & 39 & 20 & 100 & 75,90 & 22,209 \\
\hline Osjećaj sigurnosti & 39 & 20 & 100 & 66,41 & 25,699 \\
\hline Pripadnost okolini & 39 & 20 & 100 & 68,46 & 26,905 \\
\hline Sigurnost u budućnosti & 39 & 20 & 100 & 58,97 & 26,930 \\
\hline
\end{tabular}

Kako bi se dobio uvid u specifične poteškoće s kojima se pacijentice oboljele od raka dojke suočavaju te u njihovu kvalitetu života izračunate su prosječne vrijednosti na temelju rezultata upitnika EORTC QLQ-C30. Ispitanice su postigle srednje rezultate na svim funkcionalnim skalama. Emocionalno funkcioniranje u prosjeku pokazuje najniže rezultate među funkcionalnim skalama. Rezultati na skalama simptoma bilježe u prosjeku niže rezultate u područjima vezanim uz gubitak apetita, konstipaciju i diareju. Viši rezultati zabilježeni su kod novčanih neprilika, teškoća sa spavanjem i umora (tablica 3.).

Tablica 3. Prosječne vrijednosti na skalama upitnika EORTC QLQ-C30 verzija 3.0

\begin{tabular}{lccccc}
\hline Varijabla & N & Minimum Maksimum & $\bar{X}$ & SD \\
\hline Tjelesno funkcioniranje & 39 & 13,3 & 93,3 & 61 & 19,74 \\
Poslovno funkcioniranje & 39 & 0 & 100,0 & 51,3 & 35,74 \\
\hline Emocionalno funkcioniranje & 39 & 0 & 83,3 & 27,9 & 24,67 \\
\hline Kognitivno funkcioniranje & 39 & 0 & 100,0 & 50,8 & 34,61 \\
\hline Socijalno funkcioniranje & 39 & 0 & 100,0 & 49,1 & 33,76 \\
\hline Umor & 39 & 0 & 100,0 & 69,28 & 25,68 \\
\hline Mučnina i povráanje & 39 & 0 & 100,0 & 41,4 & 39,53 \\
\hline Gubitak daha & 39 & 0 & 100,0 & 36,7 & 34,02 \\
\hline Teškoće sa spavanjem & 39 & 0 & 100,0 & 70,1 & 34,87 \\
\hline Gubitak apetita & 39 & 0 & 100,0 & 29 & 31,69 \\
\hline Konstipacija & 39 & 0 & 100,0 & 37,6 & 38,37 \\
\hline Diarea & 39 & 0 & 100,0 & 26,5 & 36,01 \\
\hline Novčane neprilike & 39 & 0 & 100,0 & 69,2 & 32,79 \\
\hline Kvaliteta života globalno & 39 & 0 & 100,0 & 57 & 25,33 \\
\hline
\end{tabular}

Provjeravajući povezanost rezultata na PWI i skala dobivena je statistički značajna povezanost samo $\mathrm{s}$ varijablom koja se odnosi na gubitak apetita $(\mathrm{r}=-$ $0,321 ; \mathrm{p}=0,046)$.

Kako bi utvrdili postoji li povezanost između ispitanih domena na EORTC QLQ-C30 upitniku izračunate su korelacije koje su prikazane u tablici 4 (radi preglednosti prikazane su samo statistički značajne korelacije). Domena poslovnog funkcioniranja prema samoprocjeni ispitanica statistički je značajno povezana s domenom emocionalnog funkcioniranja, kognitivnog funkcioniranja i socijalnog funkcioniranja. Domena emocionalnog funkcioniranja statistički je značajno povezana s domenama kognitivnog i socijalnog funkcioniranja. Domena kognitivnog funkcioniranja statistički je značajno povezana s domenom socijalnog funkcioniranja. 
Tablica 4. Prikaz korelacija između subskala EORTC QLQ-C30 upitnika koje se odnose na varijable funkcioniranja

\begin{tabular}{lccccc}
\hline Varijable & \multicolumn{2}{c}{$\begin{array}{c}\text { Poslovno } \\
\text { funkcioniranje }\end{array}$} & $\begin{array}{c}\text { Emocionalno } \\
\text { funkcioniranje }\end{array}$ & $\begin{array}{c}\text { Kognitivno } \\
\text { funkcioniranje }\end{array}$ & $\begin{array}{c}\text { Socijalno } \\
\text { funkcioniranje }\end{array}$ \\
\hline $\begin{array}{l}\text { Tjelesno } \\
\text { funkcioniranje }\end{array}$ & $r$ & 0,396 & - & - & - \\
\cline { 2 - 6 } & $p$ & 0,013 & - & - & - \\
\hline $\begin{array}{l}\text { Poslovno } \\
\text { funkcioniranje }\end{array}$ & $r$ & - & 0,572 & 0,596 & 0,740 \\
\cline { 2 - 6 } & $p$ & - & $<0,001$ & $<0,001$ & $<0,001$ \\
\hline Emocionalno & $r$ & - & - & 0,566 & 0,587 \\
\cline { 2 - 6 } funkcioniranje & $p$ & - & - & $<0,001$ & $<0,001$ \\
\hline Kognitivno & $r$ & - & - & - & 0,482 \\
\cline { 2 - 6 } funkcioniranje & $p$ & - & - & - & 0,002 \\
\hline
\end{tabular}

Prema samoprocjeni ispitanica ukupna kvaliteta života najviše je povezana s poteškoćama sa spavanjem, novčanim neprilikama te probavnim smetnjama. Također, dobivena je statistički značajna povezanost pojavnosti simptoma umora, probavnih poteškoća. poteškoća sa spavanjem, gubitka apetita i novčanih neprilika (tablica 5).

Tablica 5. Prikaz korelacija izmedu subskala EORTC QLQ-C30 upitnika koje se odnose na varijable simptoma

\begin{tabular}{|c|c|c|c|c|c|c|c|c|}
\hline Varijabla & & $\begin{array}{l}\text { Mučnina i } \\
\text { povraća- } \\
\text { nje }\end{array}$ & $\begin{array}{c}\text { Poteškoće } \\
\text { sa spava- } \\
\text { njem }\end{array}$ & $\begin{array}{l}\text { Gubitak } \\
\text { apetita }\end{array}$ & $\begin{array}{l}\text { Konsti- } \\
\text { pacija }\end{array}$ & Diarea & $\begin{array}{l}\text { Nov- } \\
\text { Čane } \\
\text { nepri- } \\
\text { like }\end{array}$ & $\begin{array}{c}\text { Kvalite- } \\
\text { ta života } \\
\text { global- } \\
\text { no }\end{array}$ \\
\hline \multirow{2}{*}{ Umor } & $r$ & 0,334 & 0,469 & - & $\cdot$ & $\cdot$ & 0,490 & - \\
\hline & $p$ & 0,038 & 0,003 & - & - & - & 0,002 & - \\
\hline \multirow{2}{*}{$\begin{array}{l}\text { Mučnina i } \\
\text { povraćanje }\end{array}$} & $r$ & - & 0,319 & 0,390 & - & - & 0,390 & - \\
\hline & $p$ & - & 0,048 & 0,014 & - & - & 0,014 & $\cdot$ \\
\hline \multirow{2}{*}{$\begin{array}{l}\text { Gubitak } \\
\text { daha }\end{array}$} & $r$ & - & - & - & - & - & 0,333 & - \\
\hline & $p$ & - & - & - & - & - & 0,039 & - \\
\hline \multirow{2}{*}{$\begin{array}{l}\text { Poteškoće } \\
\text { sa } \\
\text { spavanjem }\end{array}$} & $r$ & - & - & 0,384 & 0,360 & 0,415 & - & $-0,367$ \\
\hline & $p$ & $\cdot$ & - & 0,016 & 0,024 & 0,009 & $\cdot$ & 0,021 \\
\hline \multirow{2}{*}{$\begin{array}{l}\text { Gubitak } \\
\text { apetita }\end{array}$} & $r$ & - & - & - & 0,472 & - & - & - \\
\hline & $p$ & - & - & - & 0,002 & - & - & - \\
\hline \multirow{2}{*}{ Konstipacija } & $r$ & - & - & - & $\cdot$ & 0,339 & - & $\cdot$ \\
\hline & $p$ & - & - & - & - & 0,035 & - & - \\
\hline \multirow{2}{*}{ Diarea } & $r$ & - & - & - & - & - & 0,337 & $-0,394$ \\
\hline & $p$ & - & - & - & - & - & 0,036 & 0,013 \\
\hline \multirow{2}{*}{$\begin{array}{l}\text { Novčane } \\
\text { neprilike }\end{array}$} & $r$ & - & - & - & - & - & - & $-0,418$ \\
\hline & $p$ & - & - & - & - & - & - & 0,008 \\
\hline
\end{tabular}

Zanimalo nas je i kakva je povezanost pojedinih simptoma te funkcioniranja u različitim aspektima života ispitanica. Pojava umora negativno je povezana sa svim funkcionalnim domenama kvalitete života. Pojava novčanih neprilika negativno je povezano s domenom poslovnog, emocionalnog, kognitivnog i socijalnog funkcioniranja te kvalitetom života $\mathrm{u}$ globalu. Također, utvrđena je statistički značajna povezanost mučnine i povraćanja te gubitka daha $s$ poslovnim, emocionalnim i socijalnim funkcioniranjem. Domena poteškoće sa spavanjem statistički je značajno povezana s tjelesnim i poslovnim funkcioniranjem te s kvalitetom života globalno. Prema samoprocjeni ispitanica pojava diareje negativno je povezana s emocionalnim i socijalnim funkcioniranjem te kvalitetom života globalno (tablica 6).

Tablica 6. Prikaz korelacija između subskala EORTC QLQ-C30 upitnika koje se odnose na varijable funkcioniranja i simptoma

\begin{tabular}{|c|c|c|c|c|c|c|c|c|}
\hline Varijabla & & Umor & $\begin{array}{c}\text { Mučnina i } \\
\text { povraća- } \\
\text { nje }\end{array}$ & $\begin{array}{c}\text { Gubitak } \\
\text { daha }\end{array}$ & $\begin{array}{c}\text { Poteškoće } \\
\text { sa spava- } \\
\text { njem }\end{array}$ & Diarea & $\begin{array}{l}\text { Novčane } \\
\text { neprilike }\end{array}$ & $\begin{array}{l}\text { Kvaliteta } \\
\text { života } \\
\text { globalno }\end{array}$ \\
\hline \multirow{2}{*}{$\begin{array}{l}\text { Tjelesno funk- } \\
\text { cioniranje }\end{array}$} & & $-0,421$ & - & - & $-0,532$ & - & & - \\
\hline & $p$ & 0,008 & - & - & $<0,001$ & - & & - \\
\hline \multirow{2}{*}{$\begin{array}{l}\text { Poslovno } \\
\text { funkcioni- } \\
\text { ranje }\end{array}$} & r & $-0,572$ & $-0,396$ & $-0,364$ & $-0,320$ & - & $-0,439$ & - \\
\hline & $p$ & $<0,001$ & 0,013 & 0,023 & 0,047 & & 0,005 & \\
\hline \multirow{2}{*}{$\begin{array}{l}\text { Emocionalno } \\
\text { funkcioni- } \\
\text { ranje }\end{array}$} & $r$ & $-0,451$ & $-0,370$ & $-0,396$ & - & $-0,322$ & $-0,579$ & \\
\hline & $p$ & 0,004 & 0,020 & 0,013 & - & 0,046 & $<0,001$ & - \\
\hline \multirow{2}{*}{$\begin{array}{l}\text { Kognitivno } \\
\text { funkcioni- } \\
\text { ranje }\end{array}$} & r & $-0,430$ & $-0,331$ & - & - & - & $-0,543$ & - \\
\hline & $p$ & 0,006 & 0,039 & - & - & - & $<0,001$ & - \\
\hline \multirow{2}{*}{$\begin{array}{l}\text { Socijalno } \\
\text { funkcioni- } \\
\text { ranje }\end{array}$} & & $-0,554$ & $-0,378$ & $-0,430$ & - & $-0,318$ & $-0,421$ & - \\
\hline & $p$ & $<0,001$ & 0,018 & 0,006 & . & 0,049 & 0,008 & \\
\hline \multirow{2}{*}{$\begin{array}{l}\text { Poteškoće sa } \\
\text { spavanjem }\end{array}$} & r & - & - & - & - & - & - & $-0,367$ \\
\hline & $p$ & - & - & - & - & - & - & 0,021 \\
\hline \multirow{2}{*}{ Diarea } & 1 & & - & - & - & - & 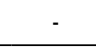 & $-0,394$ \\
\hline & p & & - & - & - & $=$ & & 0,013 \\
\hline \multirow{2}{*}{$\begin{array}{l}\text { Novčane } \\
\text { neprilike }\end{array}$} & 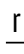 & - & - & - & - & - & - & $-0,418$ \\
\hline & $p$ & 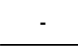 & . & . & 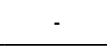 & - & - & 0,008 \\
\hline
\end{tabular}

\section{RASPRAVA}

$\mathrm{Na}$ temelju dobivenih rezultata istraživanja može se zaključiti da ispitanice oboljele od raka dojke odnose s bližnjima, pripadnost okolini i osjećaj sigurnosti procjenjuju znatno bolje u odnosu na ostale domene. Društvena podrška i obitelj najvažniji su izvor potpore pacijenticama oboljelim od raka 
dojke. Rezultati mnogih studija upućuju na zaključke da je, između ostalog, u procesu liječenja kronične bolesti neophodno aktivno uključivanje obitelji. Istraživanja i kliničko iskustvo pokazuju da je način proživljavanja, izražavanja i prevladavanja, pogotovo negativnih emocija poput tjeskobe i netrpeljivosti, ključna dimenzija obiteljske dinamike značajne za sposobnost prilagodbe obitelji u spominjanim okolnostima (18). Aktualna istraživanja ukazuju da postoje dva načina kako specifični odnosi unutar obitelji utječu na ishod liječenja kronične bolesti. Bolesnik u obitelji u svakom slučaju mijenja ustaljene obiteljske odnose. U procesu suočavanja s novonastalom situacijom, javljaju se i isprepliću različite emocije koje utječu na sve članove i uzrokuju promjenu dotadašnjih odnosa i uloga. Bolesnik postaje regresivan, ovisan o drugima. Emocionalna klima u obitelji direktno utječe na fiziološke mehanizme putem promjena u hormonalnom, imunološkom i drugim biološkim sustavima što utječe na ishod kronične bolesti. Studije su pokazale da na obitelji orijentirano liječenje kroničnih bolesti predstavlja unaprjeđenje $\mathrm{u}$ liječenju u odnosu na tradicionalno liječenje orijentirano na bolest ili pojedinačnog bolesnika, kako po pitanju rezultata liječenja i ishoda bolesti tako i u odnosu na ekonomske kriterije (19).

Većina ispitanica (61,5\%) koja je sudjelovala u istraživanju je u braku i sve su članice udruga žena oboljelih od raka dojke, što govori u prilog činjenici kako obitelj i društvena podrška ima značajnu ulogu $\mathrm{u}$ ishodu liječenja i integraciji osoba s karcinomom $\mathrm{u}$ život zajednice. Stoga rezultat dobiven u istraživanju, da su pacijentice najviše zadovoljne odnosima s bližnjima, osjećajem sigurnosti te pripadnosti okolini u kojoj žive nakon liječenja, ukazuje na potrebu da se u proces liječenja uključi kako obitelj bolesnika, tako i šira društvena zajednica, kako bi se unaprijedilo liječenje i kvaliteta života te poboljšao ishod liječenja. Spoznaja da osoba boluje od kronične bolesti, u bolesniku budi snažne emocionalne reakcije, koje su vezane uz njegovu predodžbu ili doživljaj te bolesti (20). Važnost bolesnikove predodžbe bolesti očituje se u činjenici da je cjelokupno ponašanje bolesnika određeno njegovim pripadajućim akcijskim planom nošenja s tim problemom, koji proizlazi iz njegove kognitivne predodžbe problema i uz nju vezanih emocija (21).

Procjena osobne dobrobiti nakon liječenja, kreće se u okvirima od 60 do $80 \%$ skalarnog maksimuma što se prema homeostatskom modelu smatra rezultatom unutar prosjeka koji postižu zdrave osobe. Na temelju dobivenih rezultata može se zaključiti da ispitanice oboljele od raka dojke pripadaju donjoj granici unutar prosjeka. Istraživanja pokazuju da su depresivnost i anksioznost podjednako učestale, ako ne i više od ostalih tjelesnih simptoma u onkoloških bolesnika. Ta pojavnost u velikoj mjeri varira između dosadašnjih studija u rasponu od 9 do $60 \%$, dok se u velikim studijama u kojima se rabio standardizirani psihijatrijski intervju taj raspon sužava na 10 do $30 \%$ (22). Česti su problemi i promjena perspektive o budućnosti i prijetnja mogućom smrti, promjena uloga u obitelji, te osjećaji usamljenosti, napuštenosti i stigmatizacije. Sve su to akutni izvori stresa koji se mogu javiti tijekom različitih faza bolesti, a nerijetko postaju kronična stanja koja dovode do prolongiranog stresa te posljedično uzrokuju promjene u ponašanju, kao i psihoneuroendokrinološke i imunološke promjene (23).

Rezultati provedenog istraživanja pokazuju niže rezultate na skalama simptoma koje su vezane uz apetit i probavne smetnje kao što su diarea i konstipacija. Takva stanja mogu biti posljedica primijenjenih metoda liječenja. Poznato da je da će simptomi biti jače izraženi u žena i mlađih pacijenata (do 65 godina) uspoređujući kemoterapije sličnog emetičkog učinka (24). U pacijenta s malignom bolesti uzroci proljeva mogu biti u polivalentnoj medikamentnoj terapiji (laksativi, antibiotici, antacidi, nesteroidni antireumatci-posebice indometacin i diklofenak, sirupi s disaharidima) (25). U usporedbi kvalitete života onkoloških pacijenata u prvoj godini nakon postavljene dijagnoze i opće populacije u Švedskoj, oboljeli su imali lošiju opću kvalitetu života i lošije poslovno funkcioniranje, te veći broj simptoma mučnine i diaree (26). Kao važan prisutan faktor u procjeni pokazao se umor koji ima veliki utjecaj na brojne ispitane domene. Prema Vrdoljaku i Viculinu, sindrom zloćudnog umora, (engl. fatigue), definira se kao uznemirujući 
perzistentni, subjektivni osjećaj fizičkog, emocionalnog $\mathrm{i} / \mathrm{ili}$ kognitivnog umora ili iscrpljenost koja ometa svakodnevno funkcioniranje osobe (27). To je gotovo univerzalno stanje koje utječe na fizički, emocionalni i mentalni status bolesnika, a javlja se tijekom i nakon provođenja specifičnog onkološkog liječenja, te je vrlo čest u populaciji bolesnika s uznapredovalim i neizlječivim oblicima bolesti (28). Studije provedene na populaciji oboljelih od raka pokazuju da je sindrom zloćudnog umora jedan od najučestalijih simptoma kod tih pacijenta, prisutan u 75-80 \% osoba, a ima izražen negativan utjecaj na svakodnevno funkcioniranje i kvalitetu života (29). Druge studije ukazuju da prevalencija sindroma zloćudnog umora kod bolesnika s metastatskom bolešću prelazi $75 \%$, te se u više od $30 \%$ slučajeva javlja zajedno s različitim oblicima emocionalnog stresa, poremećajima spavanja i bolnim sindromima (27). Rezultati dobiveni u ovom istraživanju ukazuju na to da rehabilitacija žena oboljelih od raka dojke nije sustavna, već se izvodi neposredno nakon liječenja, što je nedostatno u postizanju maksimalno moguće funkcionalne sposobnosti pacijentica kao i kvalitete života. Rezultati ukazuju da je samo dio ispitanica bio uključen u rehabilitaciju neposredno nakon liječenja, dok je u kasnijoj fazi nakon liječenja, manje od polovice žena uključeno u rehabilitacijski proces. Ova distribucija rezultata može se povezati sa pojavnosti umora kod ispitanica kao i važnošću stručnog vođenja tjelesne aktivnosti, primjerene dobi i stanju žene, pod vodstvom educiranog fizioterapeuta.

Savjetovanje o općim strategijama očuvanja tjelesne energije i metodama distrakcije za ublažavanje sindroma zloćudnog umora, te edukacija pacijenta i obitelji o etiologiji, značaju, terapijskim opcijama i njihovom očekivanom ishodu, bitan su aspekt terapijskog pristupa kod bolesnika na aktivnoj terapiji i onih nakon završenog onkološkog liječenja. Bolesnici se uče različitim metodama očuvanja i pažljivom planiranju potrošnje tjelesne energije na bitne aktivnosti, uz vođenje dnevnika kako bi se utvrdio specifičan uzorak pojave umora odnosno identificirale određene aktivnosti povezane s povećanom razinom umora. Na temelju ovih informacija predlažu se promjene rasporeda u obavljanju pojedinih aktivnosti uz uvođenje odgovarajućih razdoblja odmora kako bi se sačuvala neophodna razina tjelesne energije. Važno je istaknuti kako je sindrom zloćudnog umora jedna od najvažnijih i najčešćih neželjenih posljedica uznapredovalog raka ili njegovog specifičnog liječenja. Ta nas činjenica obvezuje da sindrom zloćudnog umora rano dijagnosticiramo, te ukoliko je to moguće aktivno liječimo (27).

Ovo istraživanje daje smjernice za daljnja istraživanja vezana uz kvalitetu života žena oboljelih od raka dojke. Prednost ovog istraživanja je i deskriptivna analiza kvalitete života osoba žena oboljelih od raka dojke te procjena faktora koji utječu na njihovu samoprocjenu kvalitete života u svrhu kreiranja rehabilitacijskog procesa. Uzorak je specifičan po tome što su sve ispitanice članice udruga žena oboljelih od raka dojke što se može povezati s boljom procjenom domene odnosa s bližnjima. U sljedećim istraživanjima bilo bi potrebno uključiti žene koje nisu članice udruga i ispitati njihovu percepciju dobivene podrške tj. imaju li je dovoljno te napraviti usporedbu kako bi se ispitale razlike. Upitnik EORTC QLQ-C30 pokazao se kao primjeren mjerni instrument za utvrđivanje faktora koji utječu na samoprocjenu ispitanica oboljelih od raka dojke.

\section{ZAKLJUČAK}

U skladu s postavljenim ciljevima ovim istraživanjem je utvrđeno da percipirana kvaliteta života žena s rakom dojke ne odstupa od vrijednosti koje se mogu naći u zdravoj populaciji. Većina ispitanica postigla je prosječne rezultate na svim funkcionalnim skalama, a kao važan faktor u procjeni pokazao se umor koji ima veliki utjecaj na brojne ispitane domene. U daljnjim istraživanjima bilo bi potrebno uključiti dodatne mjerne čestice te uključiti veći broj ispitanica u uzorak čime bi se dobili precizniji podaci o uzročno-posljedičnoj povezanosti kvalitete života i faktora koji utječu na kvalitetu života žena oboljelih od raka dojke. Kvaliteta života temeljena na zdravlju u onkologiji treba biti krajnji cilj rehabilitacijskog procesa za svakog onkološkog bolesnika i cijelog rehabilitacijskog tima. 


\section{LITERATURA}

1. Vrcić-Kiseljak Lj. i sur. Fizioterapija u onkološkom liječenju i rehabilitaciji - odabrane teme. Zagreb: Medicinska naklada; 2014.

2. Theriault RL, Galimberti V, Orlando L, Harder F. Challenging clinical situations. Breast. 2002;11:190-1.

3. Wyl L, Reed M. The role of surgery in the management of older women with breast cancer. EJC. 2007;43:2253-63.

4. Esteva FJ, Hortobag GH. Prognostic molecular markers in early breast cancer. Breast Cancer Research. 2004;6:109-18.

5. Krizmanić M, Kolesarić V. Pokušaj konceptualizacije pojma kvaliteta života. Primijenjena psihologija. 1989;10:179-84.

6. Petz B. i sur. Psihologijski rječnik. Jastrebarsko: Naklada Slap; 2005.

7. Fossa SD, Hess SL, Dahl AA, Hjermstad MJ, Veenstra M. Stability of health-related quality of life in the Norwegian general population and impact of chronic morbidity in individuals with and without a cancer diagnosis. Acta Oncologica. 2007;46:452-61.

8. Scialla S, Cole R, Scialla T, Bednarz L, Scheerer J. Rehabilitation for eldery patients with cancer asthenia: making a transition to palliative care. Palliative Medicine. 2000;14:121-7.

9. Schwartz AL. Daily fatigue patterns and effects of exercise of women with breast cancer. Cancer Practice. 2000;8:16-24.

10. Porock D, Janson K, Tinnelly K, Blight J. An exercise intervention for advanced cancer patients experiencing fatigue: a pilot study. Journal of Palliative Care. 2000;16:30-6.

11. Cummins RA, Eckersley R, Pallant J, Van Vugt J, Misajon R. Developing a national index of subjective wellbeing: the Autralian unity wellbeing index. Social Indicators Research. 2003;64:159-90.

12. International Wellbeing Group Personal Wellbeing Index. Melbourne: Australian Centre on Quality of Life, Deakin University, 5th Edition. 2013.

13. Kaliterna Lipovčan Lj, Burušić J, Tadić M. Indikatori kvalitete življenja. U: Psihologija u zaštiti mentalnog zdravlja. Priručnik za psihološku djelatnost u zaštiti i promicanju mentalnog zdravlja. Zavod za javno zdravstvo Sveti Rok Virovitičko Podravske Županije; 2012.

14. Aaronson NK, Ahmedzai S, Bergman B, Bullinger M, Cull A, Duez NJ et al. The European Organization for Research and Treatment of Cancer QLQ-C30: A quality-of-life instrument for use in international clinical trials in oncology. J Natl Cancer Inst. 1993;85:365-76.

15. Fayers P, Aaronson N, Bjordal K, Groenvold M, Curran D, Bottomley A, on behalf of the EORTC Quality of Life Group. The EORTC QLQ-C30 Scoring Manual, 3rd ed. European Organisation for Research and Treatment of Cancer; 2001.

16. Pinjatela R. Neke karakteristike kvalitete života osoba sa i bez malignog oboljenja. Hrvatska revija za rehabilitacijska istraživanja. 2008;44:79-98.

17. Mellor D, Cummins RA, Loquet C. The gold standard for life satisfaction: Confirmation and elaboration using an immaginary scale and qualitative intervju. International Journal of Social Research Methodology Theory and Practice. 1999; 2:263-78.

18. Fruge E, Crouch M. Bray J. Obiteljska dinamika i zdravlje U: Rakel RE: Osnove obiteljske medicine. Zagreb: Medicinska biblioteka; 2005. str. 307.

19. Diminić-Lisica I, Rončević-Gržeta I. Obitelj i kronična bolest. Medicina fluminensis. 2010;46:300-8.

20. Gruden A, Jušić A, Cividini-Stranić E. Bolesnik. U: Klein E i sur. Psihološka medicina. Zagreb: Golden marketing; 1999. str. 36-67.

21. Pendelton D, Schofield T, Tate P, Havelock P. The New Consultation Developing doctor-patient communication. New York: Oxford University Press; 2004.

22. Braš M. Epidemiologija i kliničke slike najčešćih psihijatrijskih poremećaja u onkologiji. U: Gregurek R, Braš M, ur. Psihoonkologija. Osijek: Grafika; 2008. str. 51-78.

23. Vukojević M, Perić I, Kordić M. Anksioznost i depresivnost kod onkoloških bolesnika u sveu- 
čilišnoj kliničkoj bolnici Mostar. Liječnički Vjesnik. 2012;134:208-14.

24. Dodd MJ, Onishi K, Diddle SL, Larson PJ. Differences in nausea, vomiting and ratching between younger and older outpatients receiving cancer chemotherapy. Cancer Nursing. 1996;19:155-61.

25. Doyle D. Oxford Textbook of Palliative Medicine. 3rd ed. New York: Oxford University Press; 2003.

26. Fröjd C, Larsson G, Lampic C, Von Essen L. Health related quality of life and psychosocial function among patients with carcinoid tumours. A longitudinal, prospective, and comparative study. Health and Quality of Life Outcomes. 2007;5:19.
27. Vrdoljak E, Viculin J. Moderni pristup u liječenju sindroma zloćudnog umora kod onkoloških bolesnika. Knjiga sažetaka IV. hrvatskog kongresa Potporno liječenje onkoloških bolesnika; 2011. str. 16-18.

28. Portenoy RK, Itri LM. Cancer-related fatigue: guidelines for evaluation and management. Review Oncologist. 1999;4:1-10.

29. Curt GA, Breitbart W, Cella D, Groopman JE, Horning SJ, Itri LM et al. Impact of cancer-related fatigue on the lives of patients: new findings from the Fatigue Coalition. Oncologist. 2000;5:353-60. 


\title{
THE EFFECT OF REHABILITATION ON QUALITY OF LLFE IN FEMALES AFFECTED BY BREAST CANCER
}

\author{
Karlo Ostrogonac ${ }^{1}$, Melita Rukavina ${ }^{2}$, Ivana Crnković ${ }^{2}$ \\ ${ }^{1}$ University Clinical Hospital Center "Sestre Milosrdnice", ${ }^{2}$ University of Applied Health Sciences, \\ Zagreb, Croatia
}

\begin{abstract}
INTRODUCTION: The concept of quality of life due to its multidimensionality is an indispensable guideline and an evaluation instrument in the rehabilitation process of oncology patients. Creating guidelines based on factors that impair the quality of life is necessary in order to determine the outcome of treatment of oncology patients.

OBJECTIVE: The objective of the study was to determine the level of quality of life in oncology patients after breast cancer treatment, and to determine the factors that affect the self-assessment of quality of life within the population on the basis of which it is possible to determine the guidelines in the rehabilitation process.

SUBJECTS AND METHODS: The study included 39 female respondents. We used a sample of respondents from different parts of Croatia. For the purpose of this study we used the Personal Wellbeing Index (PWI) in order to evaluate the quality of life and well-being after the completion of oncological treatment, as well as the self assessment questionnaire to asses the quality of life, EORTC QLQ-C30 version 3.0.

RESULTS: The results showed that the overall quality of life in women with breast cancer does not significantly differ from the results that have been reported in the healthy population. However, there are domains in which we can find poorer evaluations that directly influence the assessment of other surveyed areas related to the quality of life. According to the self-assessment of the respondents the overall quality of life is most associated with sleeping difficulties, financial difficulties and digestive disorders.

CONCLUSION: The objectification of factors that impair the quality of life in women with breast cancer are the starting point in the development of guidelines for the rehabilitation process in order to improve the intervention procedures in the treatment process.
\end{abstract}

Key words: quality of life, breast cancer, guidelines in creation of the rehabilitation process

Correspondence:

Karlo Ostrogonac

e-mail: ostrogonac.karlo@gmail.com

Tel.:099/5999-495

Address: University Clinical Hospital Center "Sestre Milosrdnice” Zagreb

Vinogradska cesta 29, 10000 Zagreb, Croatia 